\title{
Land Use, Ecology, and Socio-economic Changes in a Pastoral Production System
}

\author{
M. Okoti, J. C. Ng'ethe, W. N. Ekaya* and D. M. Mbuvi \\ Department of Range Management, University of Nairobi, P.O. Box 29053, Upper Kabete, Kenya
}

KEYWORDS Pastoralism. Settlement. Land Use. Environmental Impact

\begin{abstract}
This study was conducted in the northern part of Kenya, in Kakuma division, Turkana district. Kakuma is a semiarid area under nomadic pastoralism as the main activity. The presence of a refugee camp has attracted many people from within the Turkana community and also the outside community. The study aimed at documenting the effects of emergent land use changes on vegetation resources and the socio-economic environment in Kakuma. Data on vegetation density and cover was collected. Socio-economic data was collected from the local Turkana population and the settlement camp. The data was analysed using SPSS computer package and descriptive statistics. There was a significant difference $(\mathrm{P}<0.05)$ in vegetation cover and density with increasing distance away from the settlement camp. The mean tree crown cover was low near the settlement camp $(6.2 \%)$ but high away from the settlement camp $(57.7 \%)$. Mean tree density was high near the settlement camp (13 individuals/ $\left.100 \mathrm{~m}^{2}\right)$. Shrub crown cover was low $(0.9 \%)$ in the areas that had settlements. The need for fencing and building materials was the main cause of low shrub cover. The density of the shrub species generally increased as one moved away from the settlement camp $\left(17\right.$ individuals $\left./ 16 \mathrm{~m}^{2}\right)$. Herb species cover and density was high near the settlement camp $\left(68 \%\right.$ and 202 individuals $/ 1 \mathrm{~m}^{2}$ respectively $)$ but this comprised mostly of species unpalatable to livestock like Tribulus terrestris and Portulaca oleraceae. The study revealed that droughts and livestock raids in the previous years had set in motion social and ecological changes. The loss of livestock through raids and droughts encouraged sedenterization. This affected the cultural patterns and has had an effect on the rangeland condition. Lack of mobility concentrated livestock in specific areas, thus depleting the forage resources and creating conditions for soil erosion. Trading activities between the refugees and the Turkana had both positive and negative impact on the economic, social and cultural setup of the local community. The increase in population around Kakuma and the settlement camp has set in motion changes that have affected vegetation and social structures. The immediate social and economic returns from the exploitation of resources have overridden the long-term benefits. In regard to this there is a need for education on the impacts, both short-term and long-term, of the various activities on the vegetation, livestock resources and also the pastoral lifestyle.
\end{abstract}

\section{INTRODUCTION}

The arid and semi-arid lands of Kenya comprises more than $80 \%$ of the country's total land surface area and supports over $25 \%$ of the total human population and slightly more than half of the livestock population. The majority of people living here are pastoralists although semipastoral and farming communities are increasingly sett-ling here. A large part of this land is open range under nomadic pastoralism (Government of Kenya, 1978-83; Kiome and Ndiritu, 1995).

Arid and semi-arid lands are marginal having climates that are largely unsuitable for rainfed agriculture (Pratt and Gwynne, 1977). The arid zones are primarily dry thorn bushland, while the very arid zones are dwarf shrub grassland. Tempe-ratures are continuously warm to hot and little variation occurs throughout the year. Potential Evapotranspiration (PE) rates in excess of $2,500 \mathrm{~mm} / \mathrm{yr}$ are typical of the arid regions of

*Corresponding author:

E-mail:<ekaya@net2000ke.com>
East Africa (Ekaya, 1998). Long-term rainfall averages from less than $150 \mathrm{~mm}$ to $400 \mathrm{~mm}$ or more at higher elevations, the rainfall is bimodal mostly with peaks in April and November (Swift et al., 1996; Ekaya, 1998).

Ecology of arid ecosystems cannot be understood in isolation from an understanding of the pastoral society and the management of their livestock. Neither humans nor livestock could survive in arid areas without the other (Joeckes and Pointing, 1991). To maximize the use of land there are several strategies that the pastoralists have developed over the years as observed by Cossins (1983). These include, among others, keeping more than one sort of livestock, dividing livestock holdings into spatially separate units to minimize the effects of localized droughts, and establishment and maintenance of a special system of resource sharing, lending and giving of gifts to relatives and kinsmen within and outside the clan.

Various factors in the recent past have necessitated a change in the exploitation of the resources in the region. Some of the factors that have 
caused a change in the mode of resource exploitation are rapid population growth, changing pro-perty rights, insecurity, climatic changes and en-vironmental degradation (World Bank, 1989; Jones, 1973; Sinha, 1996). The setting of refugee camps in the ASAL's has also had a negative impact on the ecological integrity of the areas (Lazarus, 1993; UNHCR, 1997). A change in vegetation attributes is bound to affect or alter the traditional pastoral ecosystem since they depend on livestock resources that are maintained by vegetation.

An understanding of the interactions between the human and livestock population and the environment will help us appreciate or broaden our strategies of planning for the range resources. The objectives of the study were to assess the impact of land use on environmental quality using vegetation resources, and to develop socio-economic patterns within Kakuma division, Turkana district.

\section{MATERIALS AND METHODS}

This study was conducted in Kakuma division of Turkana district, Kenya. The district lies between longitude $34^{\circ} 0^{\prime}$ and $36^{\circ} 40^{\prime} \mathrm{E}$ and between latitude $10^{\circ} 30^{\prime}$ and $5^{\circ} 30^{\prime} \mathrm{N}$. About $96 \%$ of the district falls under eco-climatic zones IV and VI i.e. the arid and very arid respectively (Adegi-Awuondo, 1990). Rainfall patterns and distribution are unreliable and erratic, with an annual average of $430 \mathrm{~mm}$. The daily temperatures range from $24^{\circ} \mathrm{C}$ to $38^{\circ} \mathrm{C}$ (Government of Kenya, 1997). The main economic activity in the region is nomadic pastoralism. Livestock is kept mainly for food and sometimes sold or exchanged with other commo-dities.

The refugee camp was incepted in 1992 to carter for Sudanese nationals. It was supposed to be a temporary "home" until when the political situation in their country improved, for them to go back. But the camp increased in population as the security in the East African region worsened. Due to war in the East African region, nationals from Somalia, Eritrea, Democratic Republic of Congo, Uganda, Ethiopia, Rwanda and Burundi came in as refugees increasing the population of the area.

A completely randomized design (Steel and Torrie, 1980) was used in the study. Four transects, each $6 \mathrm{Km}$ long, were mapped out from the settlement camp. From each transect, six perpendi-cular line sub-transects measuring 100 $\mathrm{m}$ each were established at regular intervals of 1 $\mathrm{Km}$. There were a total of 24 line sub-transects. The sixth sub-transect on each main transect acted as the control. On each sub- transect, three plots each measuring $10 \mathrm{~m}$ x $10 \mathrm{~m}$ were marked out. A total of 72 plots were established. On each sample plot data on density and cover for trees, shrubs and herbs was collected. Within this plot there was a small plot measuring $4 \mathrm{~m} \mathrm{x} 4 \mathrm{~m}$, which was used to collect data on shrubs. A smaller plot measuring $1 \mathrm{~m}$ x $1 \mathrm{~m}$ placed within the edge of the $10 \mathrm{~m} \times 10 \mathrm{~m}$ plot was used to collect data on the herbaceous vegetation. ANOVA was then conducted for species cover and density along distance gradient from the camp. Means were separated using Duncan's Multiple Range Test (Steel and Torrie, 1980).

Socio-economic data was collected using open-ended and structured questionnaires. Focussed group discussions were also conducted with the aim of cross checking and getting more information on issues that could not be captured by the questionnaires. The data was then summarized, ranked and analyzed using descriptive statistics (Weissberg and Bowen, 1977).

\section{RESULTS AND DISCUSSION}

\section{Tree Cover and Density}

There was a significant difference in tree crown cover and density along distance gradient $(\mathrm{P}<0.05)$. Figures in Table 1 indicate a low tree crown cover and a high tree density near the settle-ment camp but a high tree crown cover and a low tree density away from the settlement camp.

The trees near the camp were cut for charcoal burning and construction. Some trees, for example Acacia tortilis and Salvadora persica

Table 1: Mean tree crown cover $(\%)$ and density along distance gradient.

\begin{tabular}{lllllll}
\hline Distance from the settlement camp $(\mathrm{Km})$ & 1 & 2 & 3 & 4 & 5 & 6 \\
\hline Mean tree crown cover $(\%)$ & $6.2^{\mathrm{a}}$ & $18.8 \mathrm{~b}$ & $28.7 \mathrm{bc}$ & $35.7 \mathrm{~cd}$ & $53.0 \mathrm{~d}$ & $57.7 \mathrm{~d}$ \\
Mean tree density & $13^{\mathrm{a}}$ & $9^{\mathrm{a}} \mathrm{b}$ & $6 \mathrm{~b}$ & $5 \mathrm{~b}$ & $6 \mathrm{~b}$ & $7 \mathrm{~b}$ \\
\hline
\end{tabular}

*Row figures with different superscripts are significantly different $(P<0.05)$. 
were coppicing. These trees were also the most impo-rtant sources of forage to livestock. Though tree crown cover near the camp was low, tree density was high. The explanation is that there was high tree recruitment and/ or tree re-sprouts but the young trees did not give much cover. Further away from the settlement camp there were big trees with much developed crown cover. Since this was further away from the refugee camp that offered market for wood products, the effects were minimal. This agrees with Lusigi (1980) in a study conducted in Marsabit.

The cutting of trees especially Acacia tortilis, denied pastoralists the tree's pods that are an important dry season feed. The resultant bare soils were subjected to wind and water erosion. The problem was exacerbated by the effect of communal land-use tenure system. The Turkana and the immigrant communities had equal access to the vegetation resources. This made them lax in protecting their environment. Communal land ownership was seen as the root of irresponsible use of land as also observed by Widstrand (1975). He argued that livestock were individually owned but the resources were owned communally. Because of this there was a tendency for the people not to take good care of the resources, since the cost of degradation will be shared by all.

\section{Shrub Cover and Density}

There was a significant difference in shrub cover and density along distance gradient $(\mathrm{P}<0.05)$. There was an increase in shrub cover between the $2-3 \mathrm{Km}$ from the camp but a reduction at the $4^{\text {th }} \mathrm{Km}$. Low density was also observed around the $4^{\text {th }} \mathrm{Km}$ (Table 2). The $4^{\text {th }}$ $\mathrm{Km}$ from the settlement camp had a relatively high number of settlements. From the study, the need for fencing and building materials exerted the most pressure on these resources. The most cut shrub species were Acacia reficiens, Abutilon frutico-sum and Cadaba rotundifolia. These were mainly cut for the construction of livestock enclosures and houses. Unpalatable shrubs like Cissus qua-drangularis, Euphorbia cuneata, and Cadaba rotundifolia had a high density and cover near the settlement camp than palatable shrub species like Abutilon fruticosum.

\section{Herbaceous and Dwarf Shrub Cover and Density}

There was a significant difference in herbaceous cover and density along distance gradient $(\mathrm{P}<0.05)$. Figures in Table 3 indicate that herbaceous cover was high near the camp, though we had a high number of livestock in this area. Economically viable species had a high relative density away from the settlement camp.

Most of the grasses were annual grasses, with few or none perennial grasses. A study conducted in Baringo showed the same trends (Little, 1996). An increase in tree cover was concomitant with a reduction in herbaceous cover. Knoop and Walker (1985) reported similar trends. They obser-ved that herbaceous vegetation can be depleted under dense woody vegetation. Grasses were over-utilized in the study area, especially near the settlement camp. This observation agrees with Skarpe (1990), in an experiment conducted in Botswana. Livestock, mainly goats graze in other areas and deposit the seeds into these areas. During the dry seasons the area looks bare, but in the rainy season the area is green. This temporal and spatial variability in annual vegeta-tion was also observed by Cully and Cully (1991) in a study conducted in New Mexico.

Table 2: Mean shrub cover and density along distance gradient

\begin{tabular}{lllllll}
\hline Distance from the settlement camp $(\mathrm{Km})$ & 1 & 2 & 3 & 4 & 5 \\
\hline Mean shrub crown cover $(\%)$ & $0.9^{\mathrm{a}}$ & $6.9 \mathrm{~b}$ & $9.8 \mathrm{~b}$ & $3.5 \mathrm{~b}$ & $7.8 \mathrm{~b}$ & $4.0 \mathrm{~b}$ \\
Mean shrub density & $2^{\mathrm{a}}$ & $7 \mathrm{bc}$ & $12 \mathrm{c}$ & $8 \mathrm{c}$ & $17 \mathrm{~cd}$ & $14 \mathrm{c}$ \\
\hline
\end{tabular}

${ }^{*}$ Row figures with different superscripts are significantly different $(P<0.05)$.

Table 3: Mean herbecous cover and density for the 10 common species used in the study

\begin{tabular}{llllll}
\hline Distance from the settlement camp $(\mathrm{Km})$ & 1 & 2 & 3 & 4 & 5 \\
\hline $\begin{array}{l}\text { Mean herb cover }(\%) \\
\text { Mean herb density }\end{array}$ & $\begin{array}{l}68.0 \mathrm{a} \\
202 \mathrm{a}\end{array}$ & $\begin{array}{l}59.7 \mathrm{a} \\
94 \mathrm{ab}\end{array}$ & $\begin{array}{l}56.4 \mathrm{ab} \\
121 \mathrm{~b}\end{array}$ & $\begin{array}{l}41.6 \mathrm{bc} \\
115 \mathrm{~b}\end{array}$ & $\begin{array}{l}38.4 \mathrm{c} \\
121 \mathrm{~b}\end{array}$ \\
\hline
\end{tabular}

*Row figures with different superscripts are significantly different $(P<0.05)$. 


\section{Range Condition}

The range condition in Kakuma was poor. The changes in range condition were seen interms of a reduction in the amount of forage available. Perennial grasses like Aristida spp. and Cenchrus ciliaris were fast disappearing and were being replaced by unpalatable species like Tribulus terrestris and Portulaca oleraceae. The land was also becoming bare due to soil erosion both by wind and water. Much of the bare land was cove-red with unpalatable shrub species like Cadaba rotundifolia and Cissus quadrangularis. The causes for changes in forage availability were rainfall changes and population increases. In many instances the rains disappear before plant maturity or seed formation and maturity causing seed impairment and a loss of regenerative poten-tial of the vegetation.

Around Kakuma town and the settlement camp, the under-storey vegetation was heavily browsed. Herlocker et al. (1994) recommended 45 days for cattle grazing around Kakuma, 90 days for sheep and goats and less than 135 for camels. The keeping of livestock around Kakuma through- out the year implies that the range resources are over-utilized, exposing this fragile ecosystem to erosion. The woody vegetation improves with distance from the settlement camp. Unpalatable species dominate in some areas. Palatable forage species like Acacia tortilis, Indigofera spinosa, Salvadora persica, Duosperma eremophylum, Balanites aegyptiaca, Indigofera cliffordiana, Aristida mutabilis and Grewia spp were rare near the settlement camp. There was a high cover of unpalatable species near the settlement camp e.g. Cadaba rotundifolia, Cissus quadrangularis, Sanseveria spp and Euphorbia cuneata. These grew mostly in wind eroded areas and on small mounds of sand dunes. In some areas, the ground was bare and eroded by wind and water.

\section{Livestock Husbandry}

From the sampled population, $97.5 \%$ of the respondents kept livestock and the remaining 2.5 $\%$ initially had livestock but lost them to either raiding or drought. The study showed that $65 \%$ of the respondents kept their livestock around the camp throughout the year, and $35 \%$ half of the year. Livestock seasonal migration has changed and many pastoralists opt to stay near the settlement camp the whole year, though some stay near the camp half the year. Of the reasons given, a small herd was the main one (35\% of the respondents) while insecurity from the outside community i.e. bandits and cattle rustlers ranked the least. Choksi et al. (1996), in a study conducted among the Rabaris of Gujarat observed that the loss of animals led to sedenterization. This concurs with the observation in the field that many of the respondents near the settlement camp and who settled throughout the year were destitute. The market created for woodfuel, livestock and building materials from the refugee camp attracted the settlement of the Turkana. The same observations were made by Mohammed (1992) in a study conducted among the Fulani of northern Nigeria. This implies that the increase in the urban population will demand an increase in the supply of fuel-wood.

The economic demand of livestock by the settlement camp and the Kakuma town acted as an incentive for sedenterization. The demand for livestock products has drawn traders from the interior that come to sell their livestock in Kakuma town. The keeping of a large number of livestock around Kakuma for sale has had an effect on the rangeland. There has been range deterioration because the number of animals surpasses the availability of forage. Heavy stocking produces short-term economic gain, but in the long run, the quality of the rangeland and livestock deterio-rates. The keeping of livestock near the settlement camp for half a year was a risk spreading strategy, in which the pastoralists spread the effects of drought and disease outbreak and also took advantage of the wet season pastures in other areas. Lusigi (1984) observed that increase in human population has tended to reduce the home ranges and concentrate animals in certain areas. This concentration of animals in certain areas has led to overgrazing and overstocking (Darkoh, 1990). Due to scarcity of forage near the settlement camp, livestock production was not sufficient to meet the peoples daily needs. Because of limited food supply they engaged in other economic activities to supplement livestock production. This was seen as a pastoral production strategy as observed by Cossins (1983).

\section{Settlement Patterns}

The survey revealed that $50 \%$ of the respon- 
dents (households) were born in the area. The remaining $50 \%$ came from the surrounding regions. Various reasons are responsible for their migration and settlement in Kakuma. The reasons, in order of importance are; droughts, raids and insecurity especially during the 198082 period, hunger, availability of forage around Kakuma, and water for the animals.

A reduction in livestock numbers coupled with lack of alternative source of livelihood has led to famine even in years of good rainfall. This was mostly observed in the families that had a small livestock size relative to family sizes without any other source of subsistence. Livestock migration and access to dry season grazing pastures was hindered affecting the production and reproduction of livestock. This also accentuated famine in the area. In this case, the families opted to look for alternative sources of money to buy food. These were the selling of charcoal, firewood and building and fencing materials to the refugee camp and Kakuma town apart from seeking for casual employment. Hunger also affected their health and the ability to move long distances with their livestock in search of forage. The start of the refugee camp in 1992 acted as an incentive to further their settlement. The camp was and has been a source of food, employment and trade.

Settlement around Kakuma was also due to various factors one of which was insecurity. Insecurity in the area was seen from two perspectives i.e. raiding by the outside communities and from internal sources. Internal sources of insecurity included thefts from the fellow Turkanas. The high demand for livestock, due to the presence of the refugee camp, has also led to the increase in livestock thefts within the commu-nity. During famine and drought years raiding is done as a source of food. There has been a clash over control of resources in the surrounding areas and to some extent confined them even the more.

It was observed that $65 \%$ of the respondents settled since the 1990 drought in which most of their livestock died. Katie, (1993) in a study conducted in Baringo reported that drought can claim up to $80 \%$ of the stock and many years of recovery can force the pastoralists to settle.

\section{Economic Activities}

There were various economic activities recorded from the respondents during the survey. The economic activities in order of importance were; selling wood-fuel, selling water, seasonal farming of sorghum, cutting and selling building poles and fencing material, collecting and selling stones for construction. From the survey $95 \%$ of the respondents said they got market for what they sold and $77.5 \%$ said they got profit, though they could not ascertain the profit in monetary terms. The profit was expended in the following ways as ranked according to their importance; purchase of food, clothing and ornaments, drugs for livestock and human health, and buying more stock i.e. restocking.

\section{Perceptions on Environmental Degradation}

The survey indicated that $97.5 \%$ of the respondents acknowledge the presence of environmental degradation. The causes from the most important to the least important are; increase in population, change in lifestyles, drought and lack of resource control. Changing lifestyles due to the influence of the population, majority of who are non-pastoral, was seen to affect the sense of communal responsibility for natural resources management.

This study revealed that there is degradation of the environment. Increase in population was one single most important factor of degradation. People within the study area made a demand mostly on the vegetation in terms of the need for browse and forage for their animals, fencing and material for constructing bomas, water resources and wood-fuel. It was seen that the demand of these resources outweighs the availability. This same phenomenon was also reported by Lusigi (1984), Ormerod (1978) and Lamprey (1983). The availability of a ready market, from within and outside the district, for charcoal, firewood, building materials, livestock, and labor had increased the pressure on vegetation resources.

\section{Positive and Negative Impacts of the Settlement Camp}

The study documented some positive impacts that the camp has introduced. It has provided a number of employment opportunities, training, schooling opportunities, and medical services which otherwise could not have been readily available, and increased marketing opportunities 
for livestock. Partly it has a negative environmental impact, of which the most significant is the cutting / burning of large mature trees to obtain the raw material for charcoal. The camp offers a market for the charcoal and fuel-wood. The majority of the people that burn charcoal around the camp are the destitute women who are not able to cope well with the pastoral system, others are the families who have their traditional homes there and have lost too many animals to be able to provide for themselves.

\section{CONCLUSION}

Insecurity in the Kakuma region has affected livestock production and the social welfare of the community. The traditional pastoral values are changing as many are forced to settle and change their mode of subsistence. Alternative lifestyles are adversely affecting the resource base and are short-term solutions. The increase in refugee population and expansion of settlements has attracted destitute families around Kakuma. This has enhanced the break-up of the traditional subsistence structures. Many of the families are not able to adapt to the former traditional pastoral ways.

Communal land tenure, though for a long time has been a good mode of resource management, has shown negative impacts. Immediate economic returns sought after by individuals has undermined the collective role of pastoral resource management. The result may be a breakdown in the ecosystem, as many people try to maximize the use of the resources to their own benefit. It was evident that pastoralists have a pronounced effect on vegetation.

Change in vegetation density and cover affected vegetation use by livestock. The latter affected pastoral production strategies, since they have to shift from keeping large stock to small stock i.e. from cattle to goats and in some instances from goats to few camels. A change in vegetation has limited or reduced the areas available to livestock species for grazing and browsing. To measure the primary production figures of the vegetation around Kakuma would be of interest in the future, so that one can well monitor the process of degradation. Certain areas could be fenced out from animals for a period of time in order to observe if the degradation would reverse naturally or if active measures are to be taken. If the soil seed bank has been depleted or it is not enough to induce natural regeneration then active reseeding could assist. This will be aimed at increasing the forage production in the area around Kakuma. Other issues that should be addressed are insecurity, restocking for families that lost their livestock in raids and droughts, and restrictions on the use of woody resources, especially charcoal burning on commercial basis to avoid over-exploitation.

\section{REFERENCES}

Adegi-Awuondo, C.: Life in the Balance; Ecological Sociology of Turkana Nomads. Acts Press, Nairobi (1990).

Choksi, A. and Dyer, C.: Pastoralists in a Changing World; Patterns of Adaptations Among the Rabaris of Kutch, Gujarat. Drylands Network Programme, 69 (1996).

Cossins, N.: Production strategies and pastoral man, pp. 213231. In: ILCA: Pastoral Systems Research in SubSaharan Africa. ILCA, Addis Ababa (1983).

Cossins, N.: Suffering Grass; Subsistence and Society of Waso Borana. Stockholm Studies in Social Anthropology 2, University of Stockholm, Department of Social Anthropology (1983).

Cully, A.C. and Cully, J.F.: Spatial and temporal variability in perennial and annual vegetation in Chaco canyon, New Mexico. Ecology Abstracts, 17 (3): 48 (1991).

Darkoh, M.B.K.: Trends in natural resource use and prospects for sustainable resource management in Kenya's arid and semi-arid lands. Land Degradation and Rehabilitation, 6(2):79-93 (1990).

Ekaya, W.N.: Primary Productivity, Energy Flow and Nitrogen Cycling in a Rangeland Ecosystem. Ph.D. Thesis, University Of Nairobi (1998).

Government of Kenya, The Netherlands Government and Republic of German: Natural land degradation assessment and mapping in Kenya, Government printers, Nairobi (1997).

Government of Kenya: 1978-83 National Dev. Plan, Min. of Finance and Planning. Govt. Printers, Kenya (1978).

Herlocker, D., Nicholson, M. and Allanson, S.: Range Management Handbook of Kenya, Vol.II, 9, Turkana District. Republic of Kenya, Ministry of Agriculture, Livestock Develpoment and Marketing (1994).

Joeckes, S. and Pointing, J.: Women in Pastoral Societies in East and West Africa. Drylands Network Programme, 28 (1991).

Jones, M.J.: The organic matter content of the Savanna soils of West Africa. Journal of Soil Science, 24(1): 42-52 (1973).

Katie, K: Taking Stock; Oxfams Experience of Restocking in Kenya. Oxfam, Nairobi (1993).

Kiome, R.M. and Ndiritu, C.G.: Desert Margins in Kenya; Definition and Characteristics in the Context of Agriculture. Paper presented in the International Planning Workshop for a Desert Margins Initiative, 2326 January, Nairobi (1995).

Knoop, W.T. and Walker, B.H.: Interactions of woody and herbaceous vegetation in South African Savanna. Journal of Ecology, 73: 235-253 (1985)

Lamprey, H.: Pastoralism yesterday and today; the overgrazing problem, pg 643-666. In: Ecosystems of the World 13; Tropical Savannas. F. Buorliere, (Ed.), New York (1983). 
Lazarus, D.: Destruction and life at a refugee camp. Our Planet, 5 (2) (1993)

Little, P.D.: Pastoralism, biodiversity and the shaping of savanna landscapes in East Africa. Africa 66(1): 37-50 (1996).

Lusigi, W.: Impact of Human Activities and Land-use Practices on Grazing Lands. IPAL Technical report no. A-3, UNESCO-MAB-UNEP (1980).

Lusigi, W.: Integrated Resource Assessment and Management Plan for Western Marsabit District, N. Kenya. IPAL technical report No. A-6, MAB-UNESCO-GoK-Germany Republic (1984)

Mohammed, M.A.S.: Pastoralists and Planners; Local Knowledge and Resource Management in Gidan Magajia Grazing Reserve, N. Nigeria. Drylands Network Programme, 32 (1992).

Ormerod, W.E.: The relationship between economic development and ecological degradation; How degradation occured in West Africa and how its progress might be halted. Journal of Arid Environments, 1 (1978).

Pratt, D.J. and Gwynne, M.D.: Rangeland Management and Ecology in East Africa. Hodder and Stoughton, London (1977).
Sinha, S.: Resisting Change? Adaptations by the Traditional Pastoralists to the Rajasthan Canal Project. Drylands Network Programme, 62 (1996).

Skarpe, C.: Shrub layer dynamics under different herbivore densities in an arid Savanna, Botswana. Journal of Applied Ecology, 27: 873-885, (1990).

Steel, R.G.D. and Torrie, J.H.: Principles and Procedures of Statistics; A Biometrical Approach, $2^{\text {nd }}$ Edn. McGraw Hill Inc., USA (1980).

Swift, D.M., Coughenour, M.B. and Atsedu, M.: Arid and semiarid ecosystems, Pg 243-269. In: East African Ecosystems and Their Conservation, T.R. McClahan, and T.P. Young (Eds.). Oxford University Press, Oxford (1996).

UNHCR (United Nations High Commissioner for Refugees): Crisis in the Great Lakes; Anatomy of a tragedy. Refugees Magazine, 117. UNHCR, Geneva, (1997).

Weisberg, H.F and Bowen, B.D.: An Introduction to Survey and Data Analysis. W.H., Freeman, San Francisco (1977).

Widstrand, J.: Rationale for pastoral economy. AMBIO, 4 (4) (1975).

World Bank: Striking the Balance: The Environmental Challenge of Development. Washington D.C. (1989). 